\title{
Review of Mark Solovey and Christian Dayé (eds.), Cold War Social Science: Transnational Entanglements (New York: Palgrave Macmillan, 2021)
}

\author{
Jefferson D. Pooley \\ Muhlenberg College \\ pooley@muhlenberg.edu \\ jeffpooley.com
}




\section{Review of Mark Solovey and Christian Dayé (eds.), Cold War Social Science: Transnational Entangle- ments (New York: Palgrave Macmillan, 2021) \\ Jefferson D. Pooley, Muhlenberg College, pooley@muhlenberg.edu}

September 2021

The stress, in Cold War Social Science: Transnational Entanglements, is on the subtitle. Indeed, the collection's eleven chapters, case by detailed case, undermine the sense that "Cold War social science" is a stable referent. The phrase, after all, suggests a bipolar emanation, from Moscow and especially Washington, out to the rest of the struggled-over world. The studies reported in Cold War Social Science, edited by Mark Solovey and Christina Dayé, show that this picture is far too simple. The book's authors describe how imported knowledge was routinely re-shaped for local purposes-and how, in some cases, traffic in ideas and practices went the other way, from periphery to center. The result is an important contribution to a field-wide effort, one that has gained momentum over the last 15 years, to complicate (and pluralize) the idea of Cold War social science.

Like many edited volumes, Cold War Social Science: Transnational Entanglements has its origins in a conference. The book's international cast of authors met a second time for a two-day workshop at Solovey's University of Toronto, which plainly sharpened the volume's editorial focus. The collection, as a result, has the character of a single, collaborative project, despite its far-flung cases, on what the editors call "Cold War transnationalism" (p. 6) in their lucid introduction. Each chapter addresses the core theme of border-crossing ideas, with explicit attention to the wider historiographical stakes. This reviewer has never encountered an edited collection with such a rich and plentiful array of cross-references among the chapters, so that almost every study calls out parallels and thematic resonances with the others. In each chapter, too, the bipolar conflict is an important backdrop, but the Cold War's specific relevance is often surprising.

The book's first three chapters, because they treat traditional EastWest geographies, help illustrate the point. Ekaterina Babintseva describes how Soviet scholars working on computerized teaching in the 1960 s filtered B. F. Skinner's behaviorist forays into "programmed instruction" through their own national preoccupation with cybernetics and a distinctive emphasis on "algorithmic thinking." Elena Aronova, in her fascinating chapter, recounts how Eugene Garfield, 
the U.S. entrepreneur behind the Science Citation Index, turned to the socialist East to both save his business and re-imagine his bibliographic product; out of the ferment, Aronova shows, came the strikingly transnational birth of the scientometrics field. Radio Free Europe's research department is Simon Ottersbach's focus. After the CIA-funded broadcaster fumbled the 1956 Hungarian uprising, Radio Free Europe regrouped by, among other things, professionalizing a research operation that proved indispensable to scholarship on Eastern and Central Europe.

The thread through these chapters is the unexpected-the break with the typical Cold War social science plot. The next three chapters turn to the "Third World" context, in the same counterintuitive key. Sebastián Gil-Riaño uncovers the decisive importance of Charles Wagley's World War II-era exposure to Brazilian institutions and lines of scholarship in shaping the U.S. anthropologist's area-studies worldview. The Philippines is at the center of Christa Wirth's chapter, which traces the career of Chicago-trained "deviant modernizer" Felipe Landa Jocano who-despite or because of his mildly decolonialized take on U.S. modernization theory-helped prop up the Marcos regime. Of all the chapters, it's Margarita Fajardo's superb chronicle of Latin American dependency theory that epitomizes the volume's revisionist spirit. Fajardo describes how dependency theory emerged in a regional context, in two partially overlapping strands richly embroidered into an already vibrant, and often critical, development discourse. It was only in the 1970s, when radical Latin Americanists in the U.S. held up a simplified and de-contextualized version as a totem of scholarly resistance, that "dependency theory" gained its status as a Latin American social science of "the other side."

A pair of chapters linger on the effort in communist states to deploy social science in the project of fashioning ideal socialist citizens. Vitězslav Sommer's chapter on the sociology of leisure in Czechoslovakia is, unlike the volume's other studies, self-sealed. Sommer tells the story of a post-Prague Spring movement in sociology to identify and promote a socialist "lifestyle" in overtly Cold War terms-a project wrecked on the reef of the state's 1980s decline. Shifts in Chinese educational philosophy and policy are the topic of Zhipeng Gao's chapter; in broad terms, a pre-revolutionary American influence gave way, for a time, to an embrace of Soviet thinking and Pavlov in particular, only to yield, after 1958 and Mao's Great Leap Forward, to a more distinctively Chinese emphasis on the pedagogy of labor.

The theme of ideas on the move appears in the volume's final trio of studies. Per Wisselgren reconstructs the "social scientific internationalism" of Alva Myrdal, as revealed in her early to mid-1950s 
stint as director of social science at UNESCO. As Wisselgren shows, Myrdal came to recognize, and call out, the center-periphery imbalances in the circulation of social scientific knowledge, largely due to her experiences in, and exposure to, India. Begüm Adalet's well-written chapter presents a fresh perspective on the case of U.S. comparative politics, drawing on archival documents to show how important figures expressed backstage doubts and anxieties about the field's behavioralist agenda and approach-as conditioned, in the chapter's two main cases, by experience with Turkey and Turkish scholars. In his sprawling, concluding chapter, Markus Arnold situates the "knowledge society" concept in the context of Cold War sparring over the place of knowledge in rival systems, with European New Leftists challenging Daniel Bell's post-ideology framing-and Austrian-born liberals like Friedrich Hayek and Karl Popper taking special aim at both clusters' faith in knowledge-based planning. So the book has come full circle: A widely circulated concept, "the knowledge society," is restored to its Cold War origins.

Cold War Social Science is an impressive, tightly edited collection, a model for tethering spread-out case studies to a unifying theme. The transnational entanglements of the book's subtitle double back on, and expand, the domain announced in the title.

Reviewed by Jefferson Pooley, Professor, Muhlenberg College, Allentown, PA, USA. 